\title{
Modelling the Effect of TPACK and Computational Thinking on Classroom Management in Technology Enriched Courses
}

\author{
Mustafa Saritepeci ${ }^{1}$ (D)
}

Accepted: 30 April 2021 / Published online: 5 May 2021

(C) The Author(s), under exclusive licence to Springer Nature B.V. 2021

\begin{abstract}
One of the fundamental obstacles associated with technology integration into educational settings is classroom management problems. In this sense, it is important to delve into the crucial factors playing key role in classroom management in ICT assisted courses. In this study, the relationship between classroom management in technology-enriched courses, computational thinking (CT) and technological pedagogical content knowledge (TPACK) was investigated. In this study, in which the relational screening research model was used, a total of 125 volunteer teachers participated. Three instruments were used for data collection in this research and the obtained data were analyzed by Partial Least Squares Structural Equation Model. The findings show that the relative effect of TPACK and CT on classroom management is significant. Additionally, it has been found that CT has a significant impact on TPACK level.
\end{abstract}

Keywords Classroom management · TPACK · Computational thinking · Technology assisted course

\section{Introduction}

Nowadays, teachers are expected to embrace technology through innovative instructions to improve the quality of educational settings in which learning and teaching activities take place, thereby actively supporting the learning actions of individuals (Drent \& Meelissen, 2008; ISTE, 2016; Pierson, 2001). However, the utilization of technology in learning and teaching activities via innovative methods and perspectives is far from expectations (Tondeur et al., 2017; Y1ldiz et al., 2013). There is evidence to suggest that although most of the teachers focus their efforts on integrating technology into their teaching, there have been tremendous differences in both quantity and quality of the utilization of technology (Spector, 2001; Tondeur et al., 2013; Y1ld1z et al., 2013). The core reason for this is to exist various factors involved that affect technology use in educational settings (Durak \& Saritepeci, 2017). Some of these factors are as follows: learning and teaching theories, in-service training quality and

Mustafa Saritepeci

mustafasaritepeci@gmail.com; msaritepeci@erbakan.edu.tr

1 Department of Computer Education and Instructional Technology, Ereğli Faculty of Education, Necmettin Erbakan University, Konya, Turkey 
continuity, curriculum, teaching method, facilities, student and teacher number, the ICT literacy levels of students, the TPACK levels of teachers, classroom management, and technical support (Durak \& Saritepeci, 2017; Muir-Herzig, 2004; Sarıtepeci et al., 2016; Y1ldız et al., 2013).

Integration of technology into classroom environment not only affects lots of factors in learning and teaching environments, but classroom management, as well. Durak and Saritepeci (2017) expressed that classroom management is a key element of meaningful integrating technology into teaching, and vice versa. In this sense, Usluel et al. (2007) reported that $19,5 \%$ of the participants voiced that utilization of technology in teaching activities makes CM (Classroom Management) difficult and this is an obstacle towards integration of technology in educational settings. It can be argued that teachers may need to update their classroom management strategies when they start to use technology in their classes (Morrison \& Lowther, 2001). Accordingly, it can be noted that CMTEC is affected by different factors when compared to typical classroom environments. One of these factors is the coping skill that is needed in ICT-based environments (Milliken \& Barnes, 2002; Muir-Herzig, 2004; Usluel et al., 2007). The obstacles encountered in technological-enriched classrooms necessitate more comprehensive and different ICT skills. In this sense, teachers may need to find solutions for the problems they encounter in technology-enriched classrooms, by using the technology itself. In solving any problem, the use of ICT tools is closely linked to computational thinking skills. In this regard, Özden (2015) defines CT as knowledge, skill, and attitude that must be obtained by the individual to employ ICT while solving real-life problems with a production-based perspective. Accordingly, it can be argued that there is a positive significant relationship between CT skills and classroom management skills in ICT-enriched classrooms.

A successful ICT integration is a must for reducing classroom management problems in technology-assisted courses. One of the preliminary conditions of a successful ICT integration is that teachers must be qualified to achieve this. Mishra and Koehler (2006) formed TPACK in order to reveal knowledge types required to integrate technology into educational settings actively by teachers. In this sense, it can be argued that TPACK levels of teachers are a fundamental factor while integrating technology into their classes. Teachers with satisfying TPACK levels may be able to find faster solutions for the possible problems arising from ICT integration (Tsai \& Chai, 2012). Accordingly, it can be argued that there is a positive significant relationship between TPACK levels and classroom management skills of teachers in ICT-enriched classrooms.

A literature review has revealed that there are a few studies about what factors affect classroom management in technology-enriched courses (Albayrak, 2014; Bolick \& Bartels, 2014; Durak \& Saritepeci, 2017; Sabanc1 et al., 2014; Uçar, 2017). In these studies, the relationships between classroom management and teachers' gender, work experience, ICT skills, daily ICT use status in technology-enriched classrooms were examined (Durak \& Saritepeci, 2017; Uçar, 2017). On the other hand, no study examining the relationship between CMTEC, TPACK, and CT skills has been encountered in the literature review. In this sense, this study is expected to contribute to the literature, by investigating the relationship between classroom management, TPACK, and CT skills in technology-enriched classroom settings.

\subsection{Purpose of the Study}

The purpose of this study is to peruse the relationship among CMTEC, TPACK, and CT. Furthermore, it has been sought to design a model that explains and predicts the 
relationship between classroom management technology-enriched courses and several variables. The research hypotheses are listed below:

$\mathrm{H} 1$ There is a positive relationship between CT skills and classroom management skills of teachers in ICT-enriched classrooms.

H2 There is a positive relationship between computational thinking and classroom management skills of teachers in ICT enriched classrooms.

H3 There is a positive relationship between TPACK levels and classroom management skills of teachers in ICT-enriched classrooms.

\section{Conceptual Framework}

\subsection{Classroom Management in Technology Enriched Courses}

One of the most significant preliminary prerequisites of sustainable learning and teaching practices in any educational setting is the skill of controlling learners (Brouwers \& Tomic, 2000). Disruptive student behaviors are encountered in all educational settings during learning and teaching processes, and so teachers need to cope with these kinds of situations (Brouwers \& Tomic, 2000). In this sense, qualified classroom management plays a significant role in achieving successful and efficient learning (Brophy, 1988; Emmer \& Stough, 2001; Garwood et al., 2017; Wills et al., 2018). In those classroom settings which are well controlled by teachers, it is thought that teachers must observe the learners' concentrations and performances, identify the expected behaviors from students, determine the classroom rules that prevent possible problems in the classroom, as well as can consistently pursue these rules and related issues (Oliver \& Reschly, 2007; Oliver et al., 2011). Changes occurring in educational settings due to the changing classroom atmosphere may lead to new problems in terms of classroom management. This also results in new factors that expand the scope of the classroom management competencies of teachers. Integration of ICT into educational settings to improve the quality of learning and teaching practices can be regarded as an example of such a situation. In this sense, Usluel et al. (2007) and Durak and Saritepeci (2017) highlight that utilization of ICT in classroom practices brings about some challenges in terms of CM. Therefore, it can be suggested that educators must embrace new challenges in classroom management in educational settings where technology is integrated to achieve a successful adaptation process. Because this situation leads to enhancement in the complexity of the CM problems in the classroom environment (Durak \& Saritepeci, 2017; Özgün \& Saritepeci, 2021-in press). In this context, it can be argued that the CT skill, which is influential in providing effective solutions in any problem-solving context (Kale et al., 2018), may have an important role in the overcoming of new classroom management difficulties that may arise in the context of ICT integration (H1).

\subsection{Computational Thinking}

Wing (2006), considering CT is a fundamental skill for everyone, conceptualizes it as problem-solving, designing systems, and understanding human behaviors, employing the essential components of computer science (p33). After several years, Wing (2014) has revised this 
definition as follows: "CT is a thinking process in which the solution of a problem is formalized as a data processing agent can effectively do". There have been different definitions of CT in the literature. Although there is no consensus on the scope and description of CT (Brennan \& Resnick, 2012), such concepts as abstraction, algorithmic thinking, analysis, debugging, problem-solving, are mostly used while defining CT (Grover \& Pea, 2013; Kalelioglu et al., 2016). It is widely recognized that Wing (2006) is a skill that CT must be acquired by everyone, as basic literacy. For this reason, CT is gaining in popularity and appears to be an important set of skills that must be acquired by the new generation (García Peñalvo et al., 2016).

ICT tools have widespread use in our daily activities, and CT skill and high-level CT play a vital role in doing these activities (Lee et al., 2014). On the other hand, educational settings are the environments in which ICT tools have been commonly employed. It can be noted that CT skill has an impact on the integration of ICT tools into learning and teaching processes by teachers in educational settings. In this sense, an active integration of ICT tools into educational settings is a fundamental issue that must be addressed. CT is one of the key skills involved in the solution of a problem as a reflection of high-level thinking skills (problemsolving, reflective thinking, creative thinking, algorithmic thinking, abstracting, debugging, etc.). In this regard, it can be argued that TPACK skill that refers to active integration of technology into educational settings is linked to CT levels of teachers (H2).

\subsection{Technological Pedagogical and Content Knowledge}

Pierson (2001) has added a new component, technological knowledge into the existing components, content knowledge (CK), pedagogical-content knowledge (PCK), and pedagogical knowledge $(\mathrm{PK})$ which are considered as prerequisite skills of qualified teachers for an effective technology integration, revealing the possible relationships among the types of these components. Mishra ve Koehler (2006) has formed the theoretical perspective of TPACK supported in the literature to explain the knowledge types for a teacher to integrate technology into teaching practices, using this relationship among the components. This theoretical framework includes three essential knowledge types CK, PK, and technological knowledge (TK), as well as four knowledge types obtained from these PCK, technological content knowledge (TCK), and technological pedagogical knowledge (TPK), and TPACK. TPACK is used for several purposes, such as improving learning and teaching process, and evaluating teachers' technology integration levels and practices in educational settings (Pamuk et al., 2015). TPACK level is the most important indicator of the integration of technology into learning and teaching practices in educational settings. This is because TPACK includes the supporting pedagogical strategies via the best content to implement pedagogical strategies effectively (Graham et al., 2009). In this sense, teachers with high level TPACK are expected to experience fewer problems arising from technology integration into educational settings. In this regard, it can be argued that TPACK skill that refers to active integration of technology into educational settings is linked to CMTEC skills of teachers (H3).

\section{Method}

In this study, a relational screening model was employed to examine the relationships among TPACK, CT, and CMTEC. The relational screening model was used to identify the alteration, or the level of the alteration that takes place between two or more variables together (Karasar, 2013). 


\subsection{The Research Model}

The research model was composed according to the relevant literature and Fig. 1 displays it. One-way arrows represent the research hypotheses addressed among the variables.

\subsection{Study Group}

Teachers from different branches who work in the secondary schools affiliated with the Ministry of National Education in Ankara city in Turkey enrolled in this study. As it is demonstrated in Table 1, the study group includes 125 teachers, 53.60\% of whom were female, while the rest $(46.40 \%)$ were male participants. Almost a quarter of the participants had a graduate degree, while the rest $(74.40 \%)$ hold undergraduate degree. Teachers who are between 30 and 40 years old form the biggest part of the population of the study group. Moreover, the mean of the work experience of the participants is 12,58 years.

\subsection{Instruments}

The Effects of Technology Use on Classroom Management Scale (ETU-CM) designed by Durak and Saritepeci (2017) includes 9 items in three subdimensions. The scale subdimensions are as follows: The management of the layout of the classroom and teaching (CM1), time management (CM2) and Interclass relationship and behavior management (CM3. Each subdimension encompasses three items. The subdimension CM1 accounted for $26,371 \%$ of the total variance, while the total variance explained was $26,420 \%$ in CM2 and $16,815 \%$ in CM3. The internal consistency of the subdimensions of the scale was calculated as 0.926 . Figure 2 shows some sample items related to the subdimensions.

Originally developed by Schmidt et al. (2009) Technological Pedagogical Content Knowledge Scale (TPACKS), was adapted into Turkish Language by Kaya et al. (2013). The scale encompasses 32 items in four subdimensions, such as pedagogical knowledge (TPACK1), technological knowledge (TPACK2), technological pedagogical knowledge (TPACK3) and technological pedagogical content knowledge (TPACK4). The Cronbach Alpha reliability coefficients for TPACKS and subdimensions were calculated as between 0.75 and 0.89 . Figure 2 shows some sample items related to the subdimensions.

Fig. 1 The research model

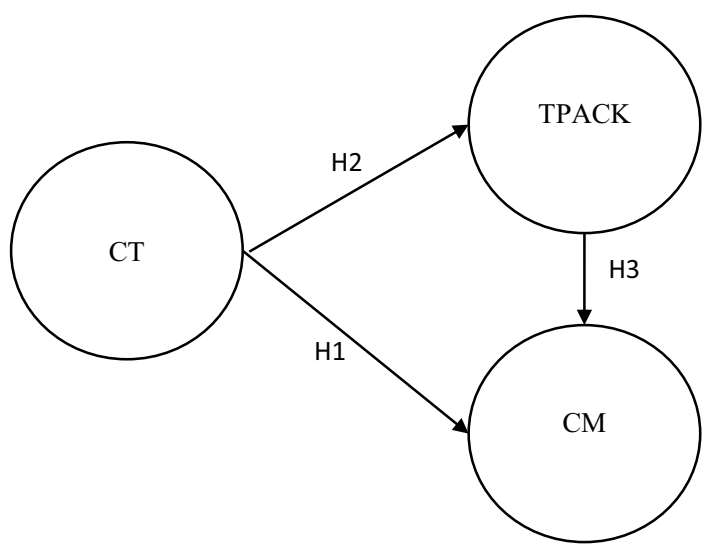


Table 1 Demographic characteristics of the participants

\begin{tabular}{llr}
\hline Variables & $\mathrm{f}$ & $\%$ \\
\hline Gender & & \\
Female & 67 & 53.60 \\
Male & 58 & 46.40 \\
Degree & & \\
Undergraduate & 93 & 74.40 \\
Graduate & 32 & 25.60 \\
Age & & \\
Below 30 & 21 & 16.80 \\
Between 30 and 40 & 60 & 48.00 \\
Above 40 & 44 & 35.20 \\
Work experience & Min. 1.00, Max. 34.00, M $=12.58$, \\
& \multicolumn{2}{c}{$\mathrm{Sd}=7.22$} \\
\hline
\end{tabular}

Computational Thinking Scale (CTS) designed by Korkmaz et al. (2017) encompasses 29 items in five subdimensions. The subdimensions are as follows: Creativity (CT1) 8, Algorithmic Thinking (CT2) 6, Cooperativity (CT3) 4, Critical Thinking (CT4) 5 and Problem Solving (CT5) 6 items. The contributions of the subdimensions to the total variance were calculated as between 8.7 and $13.5 \%$, and the scale accounted for $56.1 \%$ of the total variance. Additionally, The Cronbach Alpha reliability coefficients for CTS and subdimensions were calculated as between 0.727 and 0.869 . Figure 2 shows some sample items related to the subdimensions.

\subsection{Data Collection and Analysis}

The data were obtained through online data collection instrument. The link of the instrument was sent to the teachers who granted their consents. An instruction form on the purpose and scope of the research was sent to the participants before the procedure. Additionally, in order for obtaining confidential data, no personal information such as name, school name, has been requested from the participants.

The obtained data were analyzed by PLS-SEM (Chin, 1998; Falk \& Miller, 1992; Hair et al., 2019) in accordance with the research design. For the analysis of the data, SmartPLS 3.0 with graphical user interface (Ringle et al., 2015) was employed as it is free of charge.

PLS (Chin, 1998; Hair et al., 2016, 2019) and Linear Structural Relations (Jöreskog \& Sörbom, 1993) are the most commonly used Structural Equation Modelling (SEM) techniques. PLS is a component-based SEM technique and employs estimation procedure. In this study, PLS was preferred due to some benefits. The most important of these is that PLS-SEM is a reliable analyzing technique in studies with small samples, while the covariance-based SEM is not suitable for small groups. It is more convenient to use PLS-SEM in predictive studies which don't show normal distribution and have small sampling groups. (Hair et al., 2016).

The research model concurrently explores the model psychometric features which are measured in terms of convergent validity, discriminant validity, internal consistency (Ifinedo, 2012), and the parameters such as the degree of the relationship between the SEM variables and level of significance (Chin, 1998). Since the composite reliability and the Cronbach-Alpha reliability coefficient are above 0.7 , it has been assumed that the internal 


\section{ETU-CM}

- CM1: I can easily control the classroom when I conduct the courses with technology support.

- CM2: I can use the time efficiently when I conduct the courses with technology support.

- CM3: When I teach the lessons with technology support (tablet, interactive board, etc.), there is an increase in students' uninterested behaviors (speaking among themselves, etc.) in the lesson.

\section{TPACKS}

- TPACK1: I can adapt iny teacling style to different learners.

- TPACK2: I have the technical skills I need to use technology.

- TPACK3: I can adapt the use of tlie technologies that I am leaming about to different teaching activities.

- TPACK4: I can select technologies to use in my classroom that enhance what I teach, how I teach, and what students learn.

\section{CTS}

- CT1: Dreaming causes my most important projects to come to light.

- CT2: I can mathematically express the solution ways of the problems I face in tlie daily life.

- CT3: In the cooperative learning, I think that I attain/will attain more successful results because I ain working in a group.

- CT4: I make use of a systematic method while comparing the options at my hand and while reaching a decision.

- CT5: I cannot produce so many options while thinking of the possible solution ways regarding a problem.

Fig. 2 Sample items about instruments used in the study

consistency has been achieved (Nunnally, 1975, 1994). All reliability coefficients have been calculated above the default values 0.70 (Chin, 1998; Fornell \& Larcker, 1981). Furthermore, the average variance extracted (AVE) is over 0.50 (Fornell \& Larcker, 1981).

\section{Results}

The findings on the model based on the research hypotheses are presented in this section.

\subsection{Descriptive Analysis}

Table 2 presents the descriptive statistics related to the variables. 
As shown in Table 2, the mean score of ETU-CM is 32.06. The mean score of interclass relationship and behavior management (CM3) is higher than other subdimensions $(\mathrm{M} / \mathrm{k}=3.72)$. The TPACK scale mean score of the participants has been calculated as 99.70. The highest score has been calculated in pedagogical knowledge (TPACK1) subdimension $(\mathrm{M} / \mathrm{k}=3.94)$, whereas the lowest score has been calculated in technological pedagogical knowledge (TPACK3) subdimension $(\mathrm{M} / \mathrm{k}=3.54)$. As shown in Table 2, the mean score of Computational Thinking Scale (CTS) is 110.81. One of the subdimensions of CTS Scale, creativity (CT1) has the highest mean score $(\mathrm{M} / \mathrm{k}=4.08)$, while the lowest mean score is belonged to Algorithmic Thinking (CT2), another subdimension of CTS Scale $(\mathrm{M} / \mathrm{k}=3.50)$.

\subsection{Measurement Model}

The convergent validity has been employed to test the suitability of the measurement model. To obtain convergent validity, the prerequisites are as follows: (1) item reliability of each measure by using factor loading $(>0.7)$, (2) composite reliability of each construct $(>0.7)$ and (3) the AVE $(>0.5)$. Table 3 displays the detailed findings about the analysis.

As shown in Table 3, when the findings on the convergent validity are checked; it seems that (1) the factor loadings of all items are higher than $0.7,(2)$ the composite reliability of each item is higher than 0.7, and (3) the AVE is higher than 0.5. In this sense, it can be suggested that the measurement model supports convergent validity. Table 4 displays the correlations among the subdimensions about the validity and reliability of the measurement model.

As shown in Table 4, all correlation values have been less than diagonal values. Correlation results and the square root of the AVE value have been compared to test the

Table 2 Descriptive statistics

\begin{tabular}{llrrrrr}
\hline Scales & $\mathrm{k}^{*}$ & \multicolumn{1}{c}{ Min } & \multicolumn{1}{l}{ Max } & \multicolumn{1}{l}{$\mathrm{M}$} & $\mathrm{M} / \mathrm{k}$ & \multicolumn{1}{l}{$\mathrm{Sd}$} \\
\hline ETU-CM & 9 & 14.00 & 45.00 & 32.06 & 3.56 & 7.61 \\
CM1 & 3 & 4.00 & 15.00 & 10.45 & 3.48 & 3.09 \\
CM2 & 3 & 4.00 & 15.00 & 10.44 & 3.48 & 2.85 \\
CM3 & 3 & 4.00 & 15.00 & 11.17 & 3.72 & 2.97 \\
TPACKS & 32 & 27.00 & 135.00 & 99.70 & 3.69 & 25.90 \\
TPACK1 & 7 & 7.00 & 35.00 & 27.57 & 3.94 & 7.14 \\
TPACK2 & 7 & 7.00 & 35.00 & 25.67 & 3.67 & 7.36 \\
TPACK3 & 5 & 5.00 & 25.00 & 17.70 & 3.54 & 5.53 \\
TPACK4 & 8 & 8.00 & 40.00 & 28.78 & 3.60 & 7.94 \\
CTS & 32 & 54.00 & 143.00 & 110.81 & 3.46 & 23.20 \\
CT1 & 8 & 14.00 & 40.00 & 32.62 & 4.08 & 7.00 \\
CT2 & 6 & 6.00 & 30.00 & 20.99 & 3.50 & 7.02 \\
CT3 & 4 & 7.00 & 20.00 & 15.33 & 3.83 & 3.83 \\
CT4 & 5 & 9.00 & 25.00 & 18.38 & 3.68 & 4.65 \\
CT5 & 6 & 10.00 & 30.00 & 23.50 & 3.92 & 5.70 \\
\hline
\end{tabular}

$* k=$ number of items 
Table 3 Measurement model of the study

\begin{tabular}{llllllll}
\hline Construct & Factors & Mean & $\begin{array}{c}\text { Standard } \\
\text { deviation }\end{array}$ & Factor loading & Cronbach' alpha & $\begin{array}{l}\text { Composite } \\
\text { reliability }\end{array}$ & $\begin{array}{c}\text { Average } \\
\text { variance } \\
\text { extracted }\end{array}$ \\
\hline $\mathrm{CM}$ & CM1 & 32.06 & 7.58 & .734 & .819 & .892 & .736 \\
& CM2 & & & .941 & & & \\
& CM3 & & & .885 & & & \\
CT & CT1 & 110.81 & 23.10 & .888 & .883 & .915 & .685 \\
& CT2 & & & .788 & & & \\
& CT3 & & & .831 & & & \\
& CT4 & & & .888 & & .960 & .857 \\
& CT5 & & & .731 & & & \\
TPACK & TPACK1 & 99.70 & 25.80 & .914 & .944 & & \\
& TPACK2 & & & .920 & & & \\
& TPACK3 & & & .945 & & & \\
& TPACK4 & & & .923 & & & \\
\end{tabular}

discriminant validity. According to these findings, it is seen that the measurement model fulfils the requirements such as satisfactory reliability, convergent and discriminant validity.

\subsection{Hypotheses Testing}

All path coefficients in the inner model were analyzed through "bootstrapping procedure of 5000 samples" and "the two-tailed t-test", and the findings are presented in Fig. 3 and Table 5.

Figure 3 displays the findings on the research model path coefficients. When the path coefficients are examined, the significance order of the variables in which CM levels of the participants in technology-enriched classrooms were measured is ordered as TPACK and CT. Additionally, the relative effect of CT on the TPACK levels of teachers is significant. The results related to these relative effects are set out in Table 5.

In this research, three research hypotheses which provide evidence to suggest that the classroom management skills of teachers in technology-enriched classrooms are affected by computational thinking and TPACK levels have been formulated. As shown in Table 5, all research hypotheses have been accepted $\left(\mathrm{t}_{\mathrm{H} 1}=24.08 ; \mathrm{t}_{\mathrm{H} 2}=2.21\right.$; $t_{\mathrm{H} 3}=7.75$ ). Based on the results, it can be suggested that CT and TPACK have an impact on CMTEC. Additionally, it can also be suggested that CT skills have an impact on

Table 4 Correlations results

\begin{tabular}{llll}
\hline Construct & $\mathrm{CM}$ & $\mathrm{CT}$ & TPACK \\
\hline $\mathrm{CM}$ & .858 & & \\
$\mathrm{CT}$ & .713 & .827 & \\
TPACK & .788 & .813 & .926 \\
\hline
\end{tabular}




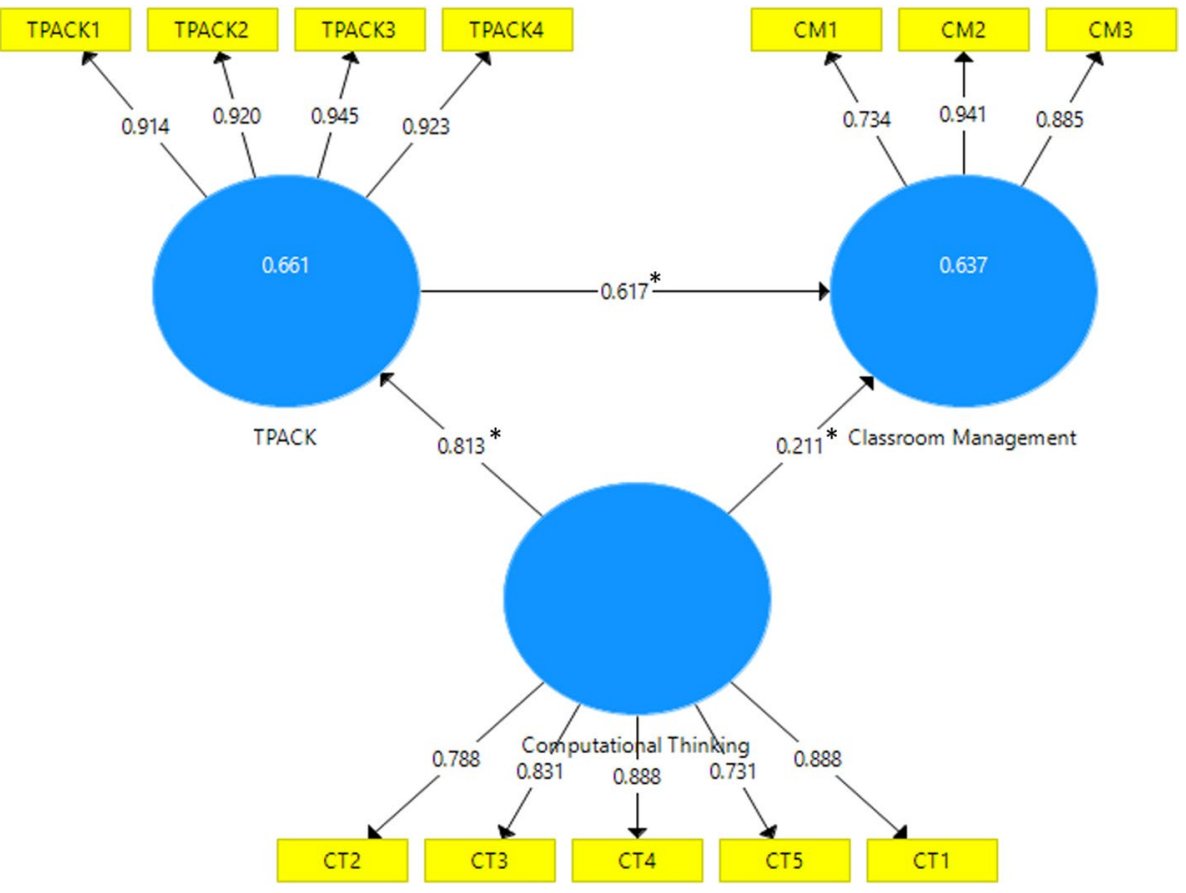

Fig. 3 The research model Path coefficients

Table 5 Hypotheses testing

\begin{tabular}{llllllrl}
\hline Hypothesis & Path & Direct effect & $\begin{array}{l}\text { Indirect } \\
\text { effect }\end{array}$ & Total effect & $\begin{array}{l}\text { Path coef- } \\
\text { ficient }\end{array}$ & t value & Accept/reject \\
\hline H1 & CT-CM & .211 & .502 & .713 & .21 & 2.21 & Accept \\
H2 & CT-TPACK & .813 & .000 & .813 & .81 & 24.08 & Accept \\
H3 & TPACK-CM & .617 & .000 & .617 & .62 & 7.75 & Accept \\
\hline
\end{tabular}

TPACK levels. Accordingly, it can be argued that each variable in this model has a positive significant impact on CMTEC.

\section{Conclusion and Discussion}

For the last decades, utilization and integration of technology in educational settings have evolved into a must rather than an option. In spite of its benefits for the classroom environment, technology may lead to some classroom management problems (Durak \& Saritepeci, 2017). In this sense, this study has delved into teachers' classroom management skills in technology-enriched classrooms in terms of their TPACK and CT level perceptions.

The findings of the study indicate that CT level has a positive impact on classroom management in technology-enriched classroom (H1). Accordingly, it can be suggested that those with higher CT levels have higher classroom management skill perceptions in 
technology-enriched classrooms. This finding can be explained the fact that computational thinking is closely associated with creating better solutions towards any problem (Durak \& Saritepeci, 2018; Shute et al., 2017; Wing, 2014). This is because effective classroom management encompasses that a teacher must have detailed information on all dimensions of the educational setting, must be able to analyze the possible problems occurring in the classroom, to take necessary precautions, as well as finding effective solutions for these problems (Djigic \& Stojiljkovic, 2011). In order to make the relationship between these two skills, behavioral and operational problems caused by learners in the classroom can be linked to the debugging, one of the most fundamental components of CT skill. Debugging refers to the competence of detecting and fixing errors that occur in a certain system (Shute et al., 2017). Considering this situation, all components in a classroom can be regarded as parts of a system. It can be suggested that teachers' debugging skill that is a significant component of CT plays key role in determining the problematic situations and finding active solutions.

There is evidence to suggest that CT levels of the participants has a positive impact on TPACK levels (H2). Moreover, the impact of CT on TPACK is the most remarkable one in the model. Accordingly, it can be suggested that CT levels of the participants has a significant effect on the TPACK of the participants. Previous research has revealed that CT skill is mostly associated with ICT skills (Durak \& Saritepeci, 2018; García-Peñalvo \& Mendes, 2018; Jenson \& Droumeva, 2016; Mouza et al., 2017). Accordingly, it can be suggested that those with higher levels of CT skills show higher levels of ICT skills. Similarly, a review of literature has revealed that there are some studies focusing on the relationship between ICT and TPACK (Angeli \& Valanides, 2005; Angeli et al., 2016). In this sense, it can be suggested that there is a significant relationship between CT and TPACK levels.

The findings show that TPACK of teachers has a significant effect on CMTEC (H3). Accordingly, it can be argued that TPACK levels of teachers prevent classroom management problems from diversifying in technology-enriched classrooms, and contribute to finding effective solutions for possible problems. Tsai and Chai (2012) lend support this, concluding that most of the problems arising from during technology integration into classroom can be solved when teachers have higher TPACK levels. Accordingly, it can be suggested that those teachers with higher TPACK levels less experience classroom management problems caused by integration of technology into classroom or can find fast solutions for problems that occur. It can be concluded that given technology-enriched classroom environments, most of the classroom management problems that occur along with technology integration into classroom stem from the insufficient knowledge and competence in integration technology into classroom. With regard to this, Sabanc1 et al. (2014) report a correlation between active ICT usage and classroom management in teaching and learning activities.

\subsection{Limitations and Suggestions}

One of the limitations in this research is the utilization of a self-reflecting data collection instrument while obtaining data on the teachers' classroom management perceptions in technology-enriched classrooms. This may reveal that teachers' classroom management perceptions in technology-enriched classrooms may not fully reflect the existing situation. Therefore, along with the self-reflecting data collection instruments, studies based on the opinions of teachers and students can be done to determine the factors involved in the classroom management skill perceptions in technology-enriched classrooms. This 
may provide detailed information about determining classroom management skills of teachers and factors affecting the classroom management skills of teachers.

The results of the study show the relative impact of CT skill on TPACK and CMTEC. In this sense, activities oriented to the development of CT skills during in-service training can be organized so that TPACK and classroom management competencies of preservice teachers or in-service teachers.

Another limitation of this study is that the number of participants remains relatively low, and the study group covers a narrow area. Mixed or quantitative research to be organized with broader participation will enable understanding the relationships between CT, TPACK, and CMTEC in more depth.

With the Covid-19 epidemic, face-to-face education has been interrupted in many countries, and education is mostly continued online. These online processes mainly consist of simultaneous lessons. Since this study covers a period before Covid-19, it can say that it has some limitations in explaining which variables related to classroom management in simultaneous lessons have become prominent. Accordingly, the research can conduct to explain how the framework of classroom management has changed in these lessons. Besides, it can say that examining the role of CT and TPACK competencies in overcoming new classroom management problems encountered simultaneous lessons will provide substantial implications.

\subsection{Implications of Research}

The results of this research are expected to contribute to previous literature on CMTEC both theoretically and practically. One of the foremost theoretical contributions of this study is to reveal a model that explains classroom management competencies in technology-enriched courses. In this model, the TPACK level is more illustrative than CT in predicting CMTEC skill level. This finding shows that TPACK can be a significant indicator of CMTEC.

The findings show that CT is a significant predictor of TPACK and CMTEC. Accordingly, it is possible to say that developing teachers' CT skills could be a substantial factor to ensure effective technology integration and effective classroom management in technology-enriched courses. Because of the strong relationship between CT and TPACK, it could be argued that activities for teaching CT skills in developing teachers' technology integration competencies in educational settings will have significant outcomes. According to it is a predicted situation for a computational thinker teacher to create efficient solutions to classroom management issues.

\section{Declarations}

Conflict of interest The author declare that it is had no conflict of interest.

Ethical Approval All procedures performed in this study involving human participants comply with the ethical standards and the 1964 Helsinki declaration and subsequent amendments or comparable ethical standards.

Informed Consent All participants in the study were informed about the application and their consent was obtained that they voluntarily participated in the study. 


\section{References}

Albayrak, E. (2014). Evaluation of the usage of information technologies in the schools included to Fatih Project by means of classroom management [In Turkish] [Master Thesis, Akdeniz University]. Antalya.

Angeli, C., \& Valanides, N. (2005). Preservice teachers as ICT designers: An instructional design model based on an expanded view of pedagogical content knowledge. Journal of Computer Assisted Learning, 21(4), 292-302

Angeli, C., Voogt, J., Fluck, A., Webb, M., Cox, M., Malyn-Smith, J., \& Zagami, J. (2016). A K-6 computational thinking curriculum framework: Implications for teacher knowledge. Journal of Educational Technology \& Society, 19(3), 47-57

Bolick, C. M., \& Bartels, J. (2014). Classroom management and technology. In E. Emmer \& E. Sabornie (Eds.), Handbook of classroom management. (2nd ed., pp. 479-495). Rautledge.

Brennan, K., \& Resnick, M. (2012). New frameworks for studying and assessing the development of computational thinking. Proceedings of the 2012 annual meeting of the American Educational Research Association, Vancouver, Canada.

Brophy, J. (1988). Educating teachers about managing classrooms and students. Teaching and Teacher Education, 4(1), 1-18

Brouwers, A., \& Tomic, W. (2000). A longitudinal study of teacher burnout and perceived self-efficacy in classroom management. Teaching and Teacher Education, 16(2), 239-253

Chin, W. W. (1998). The partial least squares approach to structural equation modeling. Modern Methods for Business Research, 295(2), 295-336

Djigic, G., \& Stojiljkovic, S. (2011). Classroom management styles, classroom climate and school achievement. Procedia-Social and Behavioral Sciences, 29, 819-828

Drent, M., \& Meelissen, M. (2008). Which factors obstruct or stimulate teacher educators to use ICT innovatively? Computers Education, 51(1), 187-199

Durak, H., \& Saritepeci, M. (2017). Investigating the effect of technology use in education on classroom management within the scope of the FATİH project. Çukurova Üniversitesi Ë̆itim Fakültesi Dergisi, 46(2), 441-457. https://doi.org/10.14812/cufej.303511

Durak, H. Y., \& Saritepeci, M. (2018). Analysis of the relation between computational thinking skills and various variables with the structural equation model. Computers \& Education, 116, 191-202

Emmer, E. T., \& Stough, L. M. (2001). Classroom management: A critical part of educational psychology, with implications for teacher education. Educational Psychologist, 36(2), 103-112

Falk, R. F., \& Miller, N. B. (1992). A primer for soft modeling. University of Akron Press.

Fornell, C., \& Larcker, D. F. (1981). Structural equation models with unobservable variables and measurement error: Algebra and statistics. Journal of Marketing Research, 18(3), 382-388

García-Peñalvo, F. J., \& Mendes, A. J. (2018). Exploring the computational thinking effects in pre-university education. Computers in Human Behavior, 80, 407-411. https://doi.org/10.1016/j.chb.2017. 12.005

García Peñalvo, F. J., Reimann, D., Tuul, M., Rees, A., \& Jormanainen, I. (2016). An overview of the most relevant literature on coding and computational thinking with emphasis on the relevant issues for teachers. Consortium, https://doi.org/10.5281/zenodo.165123.

Garwood, J. D., Vernon-Feagans, L., \& Family Life Project Key Investigators. (2017). Classroom management affects literacy development of students with emotional and behavioral disorders. Exceptional Children, 83(2), 123-142.

Graham, R., Burgoyne, N., Cantrell, P., Smith, L., St Clair, L., \& Harris, R. (2009). Measuring the TPACK confidence of inservice science teachers. TechTrends, 53(5), 70-79

Grover, S., \& Pea, R. (2013). Computational thinking in K-12: A review of the state of the field. Educational Researcher, 42(1), 38-43

Hair, J. F., Hult, G. T. M., Ringle, C., \& Sarstedt, M. (2016). A primer on partial least squares structural equation modeling (PLS-SEM). Sage Publications.

Hair, J. F., Risher, J. J., Sarstedt, M., \& Ringle, C. M. (2019). When to use and how to report the results of PLS-SEM. European Business Review, 31(1), 2-24

Ifinedo, P. (2012). Internet/E-Business technologies acceptance in Canada's SMEs: Focus on organizational and environmental factors. In E-Business-Applications and Global Acceptance. InTech.

ISTE. (2016). ISTE standards for educators. https://www.iste.org/standards/for-educators.

Jenson, J., \& Droumeva, M. (2016). Exploring media literacy and computational thinking: A game maker curriculum study. Electronic Journal of e-Learning, 14(2), 111-121

Jöreskog, K. G., \& Sörbom, D. (1993). LISREL 8: Structural equation modeling with the SIMPLIS command language. Scientific Software International. 
Kale, U., Akcaoglu, M., Cullen, T., Goh, D., Devine, L., Calvert, N., \& Grise, K. (2018). Computational what? Relating computational thinking to teaching. TechTrends, 62(6), 574-584

Kalelioglu, F., Gulbahar, Y., \& Kukul, V. (2016). A framework for computational thinking based on a systematic research review Baltic. Journal of Modern Computing, 4(3), 583-596

Karasar, N. (2013). Scientific research method: Concepts-principles-techniques [In Turkish]. (26th ed.). Nobel Publication.

Kaya, Z., Kaya, O. N., \& Emre, I. (2013). Adaptation of technological pedagogical content knowledge scale to Turkish. Educational Sciences: Theory and Practice, 13(4), 2367-2377

Korkmaz, Ö., Çakir, R., \& Özden, M. Y. (2017). A validity and reliability study of the Computational Thinking Scales (CTS). Computers in Human Behavior, 72, 558-569

Lee, T. Y., Mauriello, M. L., Ahn, J., \& Bederson, B. B. (2014). CTArcade: Computational thinking with games in school age children. International Journal of Child-Computer Interaction, 2(1), 26-33

Milliken, J., \& Barnes, L. P. (2002). Teaching and technology in higher education: Student perceptions and personal reflections. Computers \& Education, 39(3), 223-235

Mishra, P., \& Koehler, M. J. (2006). Technological pedagogical content knowledge: A framework for teacher knowledge. Teachers College Record, 108(6), 1017

Morrison, G. R., \& Lowther, D. L. (2001). Integrating computer technology into the classroom. Prentice Hall PTR.

Mouza, C., Yang, H., Pan, Y.-C., Ozden, S. Y., \& Pollock, L. (2017). Resetting educational technology coursework for pre-service teachers: A computational thinking approach to the development of technological pedagogical content knowledge (TPACK). Australasian Journal of Educational Technology. https://doi.org/10.14742/ajet.3521

Muir-Herzig, R. G. (2004). Technology and its impact in the classroom. Computers \& Education, 42(2), $111-131$

Nunnally, J. C. (1975). Psychometric theory-25 years ago and now. Educational Researcher, 4(10), $7-21$

Nunnally, J. C. (1994). Psychometric Theory (McGraw-Hill Series in Psychology). (Vol. 3)McGraw-Hill.

Oliver, R. M., \& Reschly, D. J. (2007). Effective classroom management: Teacher preparation and professional development. TQ Connection Issue Paper. National comprehensive center for teacher quality.

Oliver, R. M., Wehby, J. H., \& Reschly, D. J. (2011). Teacher classroom management practices: Effects on disruptive or aggressive student behavior. Campbell Systematic Reviews, 7(1), 1-55

Özden, Y. (2015). Computational Thinking. Retrieved 7 June from http://myozden.blogspot.com/2015/ 06/computational-thinking-bilgisayarca.html.

Özgün, Z., \& Saritepeci, M. (2021). Determination of the factors affecting teachers' perceptions of classroom management competence in technology assisted courses. Technology, Pedagogy and Education. (in press)

Pamuk, S., Ergun, M., Cakir, R., Yilmaz, H. B., \& Ayas, C. (2015). Exploring relationships among TPACK components and development of the TPACK instrument. Education and Information Technologies, 20(2), 241-263

Pierson, M. E. (2001). Technology integration practice as a function of pedagogical expertise. Journal of Research on Computing in Education, 33(4), 413-430

Ringle, C. M., Wende, S., \& Becker, J.-M. (2015). SmartPLS 3. Boenningstedt: SmartPLS GmbH, http:// www.smartpls.com.

Sabancı, A., Özyıldırım, G., \& Imsır, R. (2014). The effect of ICT usage on the classroom management: A case study in language teaching. International Review of Social Sciences and Humanities, 7(1), $232-245$

Sarıtepeci, M., Durak, H., \& Seferoğlu, S. S. (2016). Examination of teachers' in-service training needs in the field of instructional technology: An evaluation in light of applications implemented at FATIH project. Turkish Journal of Computer and Mathematics Education (TURCOMAT), 7(3), 601-620

Schmidt, D. A., Baran, E., Thompson, A. D., Mishra, P., Koehler, M. J., \& Shin, T. S. (2009). Technological pedagogical content knowledge (TPACK) the development and validation of an assessment instrument for preservice teachers. Journal of Research on Technology in Education, 42(2), 123-149

Shute, V. J., Sun, C., \& Asbell-Clarke, J. (2017). Demystifying computational thinking. Educational Research Review, 22, 142-158

Spector, J. M. (2001). An overview of progress and problems in educational technology. Interactive Educational Multimedia: IEM, 3, 27-37

Tondeur, J., Kershaw, L., Vanderlinde, R. R., \& Van Braak, J. (2013). Getting inside the black box of technology integration in education: Teachers' stimulated recall of classroom observations. Australasian Journal of Educational Technology. https://doi.org/10.14742/ajet.16 
Tondeur, J., van Braak, J., Ertmer, P. A., \& Ottenbreit-Leftwich, A. (2017). Understanding the relationship between teachers' pedagogical beliefs and technology use in education: A systematic review of qualitative evidence. Educational Technology Research \& Development, 65(3), 555-575

Tsai, C.-C., \& Chai, C. S. (2012). The" third"-order barrier for technology-integration instruction: Implications for teacher education. Australasian Journal of Educational Technology. https://doi.org/10.14742/ ajet. 810

Uçar, A. (2017). Investigation of classroom management perceptions of teachers in technology assisted courses in terms of various variables [Master, Gazi University]. Ankara.

Usluel, Y. K., Mumcu, F. K., \& Demiraslan, Y. (2007). ICT in the learning-teaching process: Teachers' views on the integration and obstacles. Hacettepe Universitesi Egitim Fakultesi Dergisi-Hacettepe University Journal of Education, 32, 164-178

Wills, H., Wehby, J., Caldarella, P., Kamps, D., \& Swinburne Romine, R. (2018). Classroom management that works: A replication trial of the CW-FIT program. Exceptional Children, 84(4), 437-456

Wing, J. (2006). Computational thinking. Communications of the ACM, 49(3), 33-35

Wing, J. (2014). Computational thinking benefits society. 40th Anniversary Blog of Social Issues in Computing, http://www.utad.pt/vPT/Area2/eventos/Documents/Artigo\%203.pdf.

Yıldız, H., Sarıtepeci, M., \& Seferoğlu, S. S. (2013). A study on the contributions of the in-service training activities within the scope of FATIH project to teachers' professional growth in reference to ISTE teachers' standards. Hacettepe University Journal of Education, Special, 1, 375-392

Publisher's Note Springer Nature remains neutral with regard to jurisdictional claims in published maps and institutional affiliations. 